\title{
ON THE ECONOMICS OF HAPPINESS: THE INFLUENCE OF INCOME AND NON-INCOME FACTORS ON HAPPINESS
}

\author{
Darma Mahadea
}

School of Accounting, Economics and Finance, University of Kwazulu-Natal

Accepted: October 2012

\begin{abstract}
The quest for individual happiness and a better life for all is an important economic objective in countries as different as South Africa and France or Zimbabwe and Bhutan. Economists have focused attention on the effects of consumption, income and economic growth or development on well-being and whether economic growth can be the sole basis for delivering prosperity (Dutt \& Radcliff, 2009; Jackson, 2010). The search for happiness is an important individual and national economic goal. In the Benthamite utilitarian tradition, happiness is the sum of all pleasures and pains. People often obtain or perceive their happiness from what they have in comparison with others. At the macroeconomic level, more happiness may come from a sustained growth in GDP that enables households to enjoy an improved quality of life, with rising income, consumption and employment opportunities. At the microeconomic or individual level, more income may also enable people to live happier and fuller lives relative to those who are poor. But this accounts for only a small contribution to happiness. Life circumstances, such as marital status, health, having children and the nature of the working environment statistically make a greater contribution to happiness than income.
\end{abstract}

Key words: subjective well-being, economic growth, income, debt, happiness, debt, relationships

JEL: D1, E2, I3, J1

\section{Introduction}

"In my view, the prime purpose of social science should be to discover what helps and what hinders happiness." (R. Layard)

The quest for individual happiness and a better life for all is an important economic objective in many countries as diverse as South Africa and France or Zimbabwe and Sweden. All of us want to be happy and lead more fulfilling lives, but not everybody is happy. In former times, happiness was studied mainly by philosophers and psychologists. In recent years, though, happiness has been a topical subject in Economics too. The Economic Journal states: "Economists from different backgrounds .... all believe that happiness must play a more central role in economic science again" (Dixon, 1997:1812). Psychologists are examining happiness through brain signals, personality traits and environmental factors. Philosophers have probed happiness by looking at the maximization of pleasure and the minimization of pain, and virtuous life qualities. Some social scientists consider the effects of friendship, family, communities and groups on happiness. Economists have focused on the influence of consumption, income and economic growth or development on well-being, and are debating whether economic growth can be the sole basis for delivering prosperity, and whether income buys happiness (Dutt \& Radcliff, 2009; Jackson, 2010). It is popularly believed that happiness increases when people consume more goods and services with rising income.

Many individuals seek happiness by acquiring wealth, or working long hours to make money, often at the expense of leisure and good social relations. They believe that happiness lies in material possessions, through the satisfaction of material desires. Income is earned primarily through employment. The more income individuals can earn, the more goods and services they can afford to buy and the more satisfaction they can enjoy. In utilitarian theory, more income is better, as it enables individuals to maximize utility through a greater demand for goods and services. At the national level, the aggregate annual value of final goods and services 
produced in the country is its GDP, which serves as a basis for measuring economic growth.

More goods being produced entails more demand for labour, more employment and more income generation to buy the goods and services produced. As economic growth increases real per capita income, people can afford to buy more goods and services. This, in turn, may result in enhanced well-being and subjective happiness. It is thus no surprise that certain former and current top policy-makers, such as Nicholas Sarkozy and David Cameron, support the measurement of national wellbeing or happiness rather than GDP (Porter, 2011).

Economic reasoning would suggest a positive relationship between income and happiness. Empirical studies suggest that higher income resulting from high rates of economic growth contribute to poverty alleviation and greater life satisfaction in low income countries (Layard, 2007). Higher income raises the happiness of the poor at a point in time and place. In developed countries, a higher income does not seem to 'buy' greater happiness over time, once a threshold level of income is reached (Easterlin, 2001; Frey \& Stutzer, 2002; Layard, 2006). As the study of happiness gains a wider perspective, other factors, such as social capital (relationships) and human capital (education) are emerging as key determinants of subjective well-being. Does income contribute to happiness in a developing country? If increases in income and consumption do not make people significantly happier, at least beyond a certain level, what economic choices and environmental conditions do? This exploratory study examines the influence of income and non-income factors on happiness.

\section{2}

\section{Literature review on happiness}

In order to enhance the happiness of members of society, one needs an understanding of 'happiness' and the contributing factors. Happiness is an elusive concept, which is not defined in a definite way in the literature (Porter, 2011). Classical economists argue that more wealth is just a means of being happy (Smith, 1759:166), and 'to increase the wealth of a state tends also, generally speaking, to increase happiness' (Malthus, 1798:303). Veenhoven (1993) defines happiness as the degree to which an individual judges the overall quality of his or her life as being favourable. Recent studies show that happiness increases with income and entire nations could be happier with an expansion in economic growth (Veenhoven \& Hagerty, 2006:21). The traditional economic view is that "more is better.' So as GDP per capita increases, consumption rises, and so does aggregate wellbeing. $\mathrm{Ng}$ (1997) argues that at the micro level, each of us wants money, not for its own sake, but for what it can bring us in terms of happiness.

Economics has traditionally viewed happiness in terms of subjective well-being. In terms of economics, happiness takes reported subjective well-being as a proxy for utility (Frey \& Stutzer, 2002). Ng (2006) defines happiness as 'welfare', while for Oswald (1997), happiness means hedonistic 'pleasure' or 'satisfaction'. Layard (2011) regards happiness as enjoying life and feeling good, and is thus synonymous with subjective well-being (SWB). Individuals are said to have high SWB if they experience high-life satisfaction and frequent pleasant emotions such as joy and affection, and only infrequently experience unpleasant emotions. Easterlin (2001:465) views happiness from a broader perspective: "I use the terms happiness, subjective well-being, satisfaction, utility, welfare interchangeably".

According to the Utilitarian and Benthamian philosophy, the individual's conduct and government policies should be directed toward promoting the greatest happiness for the greatest number of people and minimizing pain, enabling a rightward shift in the social welfare function. Bentham's 'greatest happiness principle' is universal. In his 'Theory of Moral Sentiments', Smith $(1759: 232)$ postulated that leaders should "secure the internal tranquility and happiness" of their fellow-citizens.

Research indicates a link between happiness and income. People with higher incomes have a higher status in society, which intrinsically makes them happy and enables them to enjoy positional goods. These are exquisite and expensive goods that are scarce in some absolute or socially imposed sense, subject to crowding through extensive use. In this sense, 
"income does buy happiness" (Frey \& Stutzer, 2002:40). High income earners can augment their own happiness and that of poorer people too through their altruistic actions and donations of money to charitable organizations (Black, Calitz \& Steenkamp, 2003). The marginal significance of a Rand gained in utility to the poor is more than a Rand lost in utility to the rich. Happiness has a positive contagion or externality effect, as individuals with high income can make other people happier just by being happy themselves.

The behavioural school, in particular Daniel Kahneman, the Nobel Prize winner for Economics in 2002, treats happiness as a subjective issue that is measurable through surveys. This is made possible by asking respondents, for example, how happy they are on a scale (1 to 10), at a given moment and over time (Layard, 2006). Frey and Stutzer (2002:405) argue that, in evaluating happiness in relation to income and other factors, it is sensible in Economics to rely on the judgments of people as they are thought to be the best judges of the overall quality of their own lives. Stutzer (2001:37) asserts that the measures of subjective well-being have a "high consistency, reliability and validity", as well as a high stability over time (Konow \& Earley, 1999).

\section{3}

\section{Income and happiness paradox}

At any given time, richer people claim to be happier than poorer people. In developing countries, higher income raises the happiness of poor people living below the bread line. In developed and richer countries, higher income does not seem to 'buy' higher happiness, once a threshold level of income has been reached. Several studies show that, on average, individuals in wealthier countries are happier than those in poorer countries, and there is a significant relationship between happiness and income at a particular point in time and in a given country (Oswald, 1997; Frey \& Stutzer, 2002:10).

Although real income per head has increased significantly in developed countries, like America, Japan and Europe, studies using data from the past five decades, have indicated that people there, on average, are currently no happier than in earlier times (Layard, 2011).
This suggests that happiness levels fail to rise significantly as rich countries become even richer. This seems like a paradox. Easterlin (2001) argues that absolute income matters to individual happiness up to a point, but once basic needs have been met, relative income matters more for happiness. People compare their incomes and style of living with those of others in the income distribution. Raising everyone's income does not raise everyone's happiness because, in comparison with others, income has not improved (Easterlin, 2001:481).

Individuals seeking more income to increase their happiness are unlikely to be satisfied, as they aspire to getting more and more. As they earn higher income, their aspirations change. They feel dissatisfied with what they have and they may wish to possess more material goods and indulge in conspicuous consumption, possibly by contracting debt. The lack of satisfaction with what individuals currently have and their need to emulate the habits of celebrities or others, partly because of consumerism, and trying to "keep up with the Joneses" prompt them to buy more. Although many catch the 'luxury fever', this 'affluenza' and status do not necessarily make them permanently happier (James, 2007; Frank, 1999).

While these status competitions and consumption patterns increase material throughput (Jackson, 2010), they can make individuals vulnerable to depression, anxiety, substance abuse and personality disorders, all of which detract from happiness (Wilkinson \& Pickett, 2010). Further, while more income resulting from economic growth can lead to more comfort, increased choices and richer lives, this may also lead to less stimulation and more disparities, possibly contributing to a "joyless society" (Scitovsky, 1992; Jackson, 2010).

As people buy more on credit, and consume more, they do not save enough and their level of debt increases. High levels of outstanding debt, other than home mortgaged debt, can reduce their happiness (Dutt, 2008). This debt would be an added burden in their lives, if credit were taken simply for consumption motives. It is partly against this background that the National Credit Act was introduced in South Africa in June 2007 as a way of protecting consumers from accumulating high debt that they cannot afford. However, debt 
may not necessarily be an impediment to happiness if it is directed towards investment with a potential for generating higher income. Increased debt, in this instance, could actually enhance happiness when the investment payoffs lead to increased financial security.

\section{4}

\section{Non-income influences on happiness}

Individuals earn an income primarily from supplying their labour services and talents to the market. People with more education are generally more productive and earn more; they tend to be happier than those with less education. Hinks and Gruen (2007) found that South Africans with tertiary education are happier than those who have no education.

Research indicates that people with more capabilities and freedom, tend to earn more income and, are happier than those with fewer skills; individuals in democratic societies are happier than those who live under repressive regimes (Sen, 2010). Living in an environment of economic and social security has a powerful impact on an individual's well-being (Inglehart, 2009). The quality of the relationships one has at work, in the community and in the family environment has a bearing on individual happiness. Individuals with better family ties, with children and friendships and a good working environment, are happier than others for whom these qualities are lacking. Thus, social capital impacts on the well-being of the individuals (Dutt \& Radcliff, 2009).

Social connectivity keeps individuals less isolated, better supported, more bonded and thus happier (Putman, 2001; Lane, 2000). Further, people who have good health and who are more extroverted are happier than others. The happiest group tends to experience generally positive feelings (Diener \& Seligman, 2002). Intrinsic religious commitment tends to have a positive effect on life satisfaction as it often promotes virtuosity, spirituality and the values of caring concern for others and mankind (Hamilton, 2004). Further, married people tend to be happier than those who are single, divorced or widowed (Oswald, 1997; Layard, 2006). Powdthavee (2007) found that South Africans in civil marriages are significantly happier than people who are single and have never married. In short, Layard (2011) identifies seven factors influencing happiness. Listed in order of 'importance', these are: family relationships, financial situation, work, community and friends, health, personal freedom and values.

Although South Africa is at a medium level of human development (ranked $123^{\text {rd }}$ out of 187 countries), its perceived overall life satisfaction index over the period 2006-2010 stands at 4.7. This is below the average of the same development group, 4.9, and below the global average figure (5.3) (Human Development Report, 2011). However, according to the World Database of Happiness, South Africa had an average level of happiness or life satisfaction of 5.8 over the period 2000-2009. Life satisfaction is based on a scale of 1 (dissatisfied) to 10 (most satisfied). The average level of happiness, as measured by the World Value Survey question: "All things considered, how satisfied or dissatisfied are you with your life as a whole these days?", actually decreased from 6.8 in 2006 to 6.31 in 2007 and to 4.95 in 2008 (Veenhoven, 2012). This clearly shows that people in South Africa have been experiencing, on average, a reduced level of life satisfaction in recent years. This may arise partly because of high levels of unemployment, poverty and inequality (Vavi, 2011).

\section{5}

\section{Economic growth and income growth in South Africa}

Income and its increase matter a great deal to happiness when people live in poverty. Over the past 17 years, since the dawn of democracy in South Africa, the country has consistently registered positive economic growth rates, as high as an average rate of 5.5 per cent during the period 2005-2007, an average of about 1 per cent in the recessionary period 2008 and 2009 (SARB, December 2010), and 2.8 per cent in 2010 (SARB, 2011). Economic growth improves human welfare and happiness. In his book 'The moral consequences of economic growth', Benjamin Friedman (2006) argues that economic growth is a vital precondition for social progress and happiness. People whose incomes are growing rapidly find it much easier to be generous to others, unlike 
those whose incomes are static or declining in real terms. Real GDP per capita has increased from R28536 in 1994 to R36591 in 2010 (SARB, 2011). But does higher income contribute to greater happiness?

\section{6}

\section{Sample particulars}

This study explores the relationship between the level of income and happiness, in the form of a survey carried out in the greater Durban region of South Africa. A questionnaire was used to gather data on the respondents' selfreported level of happiness on a Likert scale 1 (least happy) to 5 (most happy) and their socioeconomic attributes. The question on selfreported happiness has evident face validity. It clearly addresses happiness, as defined even in the World Database of Happiness. Previous research has also shown high internal validity as expressed in consistency of responses to this similar question: 'Taking all things together, how would you rate your quality of life/level of happiness? (Layard, 2011; Veenhoven, 1997). This suggests a subjective appreciation of life. It is the subject who makes the appraisal of their subjective well-being or happiness and who is the best judge of their true level of life satisfaction.

Respondents had to self-rate their happiness on a multi-item questionnaire and scale. Researchers need to gather information on different life domains to understand what makes for happiness (Veenhoven, 1997). Accordingly, the questionnaire, administered in face-to face interviews, also sought information on the respondents' income, education, types of debt, and demographic background. All these variables were treated as categorical factors. Questions relating to their health, work environment, debt, friendships, and religion were measured on a ten-point Likert scale, enabling respondents to indicate their opinions on how strongly each factor influenced their personal happiness. Respondents were requested to rate the extent to which the latter variables contributed to their personal happiness, on a 1 to 10 scale, with low values reflecting "no" or " low importance" and the highest value (10) indicating most important. Reliability is the consistency of a questionnaire and can be reflected by the
Cronbach's alpha. In this case, the Cronbach's alpha was just under 0.7. Although values in the Cronbach's alpha greater than 0.7 are seen as indicating a good overall reliability, a slightly lower value is acceptable (Coakes \& Steed, 2003).

The data was analysed by using SPSS. The sample was chosen by random selection. The sample size is rather limited $(n=220)$ owing to resource constraints, but it is proportionally drawn according to the population dynamics of the region. The small sample and its exclusive focus on the Durban region is a limitation of the study. Nevertheless, certain pointers to happiness are discernible, though a larger sample covering more regions, and variables with intermediating influences, and stronger statistical approaches may be preferable for future research.

The sample consisted of 151 black, 45 Indian, 18 white and 6 coloured individuals. There were 114 female and 106 male respondents. Of the sample, 151 were single, 61 married, 6 divorced and 2 widowed. As far as age was concerned, 120 were in the $18-30$ group, 74 in the 31- 45 group, 21 in the 46-60 group and 5 were retired. The aim of the study was to capture the quantitative and qualitative sources of happiness, then consider whether non-income factors are more important than income in contributing to happiness and examine whether happiness varies with gender.

\section{7}

\section{Methodology and results}

Initially, the surveyed variables, education, number of children, debt and gender, as independent factors, and happiness as the dependent factor, were fitted into a multiple regression analysis, and they were all found not to be significant, except for income. As a result, only income and happiness are used in the analysis. The methodology thus used is the GLM regression analysis, in which the level of (self-reported) happiness $(\mathrm{H})$ is the dependent factor, income is (Y), a is the intercept, $b$ is partial regression coefficient of the independent factor, and e is the error term, expressed in the equation below.

$$
\mathrm{H}=\mathrm{a}+\mathrm{bY}+\mathrm{e}
$$


Consistent with other studies (Powdthavee, 2011; Layard, 2007), happiness was examined along a continuum, from least happy (1) to most happy (5). Income was measured along a continuum from low (R1000) to high (R18000 and above). Both variables were treated as continuous variables (Powdthavee, 2011). The GLM method was used because the dependent variable in the regression is non-normal; accordingly the conventional regression may not work. A regression approach was also used by Hinks and Gruen (2007) and by Powdthavee (2007) in their studies on happiness in South Africa.

Thereafter, a factor analysis and a principal component analysis with a Varimax rotation were undertaken. The factor analysis was similarly used by Heukamp and Arino (2011) in their study on the subjective well-being of different characteristics in various countries. The usual chi-square test is used to examine the association between gender and types of debt and t-test to examine the differences in happiness between the male and female group. The results are presented in two stages. Initially the descriptive findings are presented, after which they follow the regression results. Finally, there is a discussion of the findings of the factor analyses.

\section{8}

\section{Descriptive results}

The study found that the majority of the people surveyed were happy. Only 4.1 per cent reported being "not happy at all"; 8.2 per cent reported "not being very happy", 36.4 per cent reported being "fairly happy" and 33.2 per cent reported being "very happy" and another 18.2 per cent reported being "extremely happy".

The gross monthly income of the respondents ranged from R1000 to R18000 and more. In the low income group R1000- 2000, there were 31.4 per cent of the respondents, 26.8 per cent were in the R2001-R4000 group; 19.1 per cent were in the R4001-R8000 group and 22.7 per cent in the R14001 - R18000 and more group.

Regarding the education of the respondents, 8.6 per cent had a low level of education, between Grades 4 and 11, 57 per cent had Matric, 30.5 per cent had a university degree or tertiary education and about 4 per cent had a postgraduate education.

The effect of gender on happiness was examined by comparing the mean happiness levels of women $(n=114)$ and men $(n=106)$ in the sample. Women reported a mean happiness level (3.61) marginally higher than that of the men (3.44). However, the difference was not found to be statistically significant $(\mathrm{p}=0.492)$. This result is similar to that of Hinks and Gruen (2007).

Married people are reportedly happiest, with a mean happiness score of 3.61. Single people had a mean happiness score of 3.51, divorced people had a mean happiness of 3.50 and widowed people had an average happiness score of 3 .

When it came to debt, 27 per cent of the respondents reported that they did not use credit. Among those who contracted debt, female respondents used more credit cards only (14.9 per cent) than did males (8.5 per cent), had more car loans only ( 1.8 per cent $)$ than did males ( 0.9 per cent) and had more instore accounts only ( 31.6 per cent) than males did (22.6 per cent). The Chi-square test indicated that there was a significant association between gender (being female) and types of debt $\left(X^{2=} 18.56 ; p=0.046\right)$.

\section{9}

\section{Regression results}

The regression results show that income is a significant predictor of happiness ( $\mathrm{R}-\mathrm{Square}=$ 0.057; $\mathrm{p}=0.013, \mathrm{~F}=3.234)$. Despite this, the explanation is rather weak, claiming only about 6 per cent of the variation in happiness. But finding a weak connection between income and happiness is similar to other studies on happiness in the literature (Frey \& Stutzer, 2002; Ng, 2006; Biswas-Diener, 2007; Mahadea \& Rawat, 2008). In effect, typical studies in developed countries, and even those using more sophisticated multilevel analysis, have found that, at most, income explains only about 2- 4.5 per cent of the difference in happiness between individuals (Saris, 2001; Hsieh, 2004; Ahuvia, 2012). According to set point theory, people have a natural level of happiness that is set largely by their genetics and personality. However, there may be occasional departures from the mean point, for 
instance when there is a lottery win or positive exogenous event, but the average level reverts to the equilibrium set point soon afterwards. About 50 per cent of the variance in subjective well-being is apparently genetically determined, and the remainder may be accounted for by intentional activities, i.e what the people do for good or ill, and by circumstances (Sheldon \& Lyubomirsky, 2009). As income is found to be explaining only a small proportion of the variation in happiness, one is interested in other possible factors that could be associated with subjective well-being. This prompted us to use factor analysis. However, it must be pointed out the factor analysis is not about causality; it is about finding groupings of similar variables that are correlated into principal component groups, related in this case to happiness.

\section{0}

\section{Factor analysis}

To capture the influence and significance of other non-factors on happiness, a factor analysis and a Principal Components analysis with Varimax Kaiser normalization is undertaken. The factor analysis is used to reduce a large number of variables to a smaller set of underlying factors that can explain happiness. The principal component analysis decomposes the original data into a set of linear variables and shows how a particular variable might contribute to that component (Field, 2009). This approach is suitable because it takes into account unobserved variability in the measured variables. This in turn gives us the most influential factors affecting happiness.

A set of seven factors with Eigen values greater than 1 emerged as key clusters influencing happiness. The first component, consisting of two factors, has an Eigen value of 2.022, and it explained 14.4 per cent of the variation in happiness (Table 1). The two factors of substantive importance influencing happiness are marital status and the number of children (Table 2), with a weight of 0.828 and 0.822 respectively.

The second set has three factors (health, working environment, and religion with loadings $0.809,0.731,0.570$ respectively). This component has an Eigen value of 1.805 , and it explained 12.8 per cent of the variation in happiness (Table 1 and Table 2). Of these factors, health and the work environment are found to have a greater influence on happiness than religion does.

Table 1

Total variance explained

\begin{tabular}{|c|c|c|c|c|c|c|c|c|c|}
\hline \multirow{2}{*}{$\begin{array}{c}\text { Table 1: } \\
\text { Component }\end{array}$} & \multicolumn{3}{|c|}{ Initial Eigenvalues } & \multicolumn{3}{|c|}{$\begin{array}{l}\text { Extraction sums of squared } \\
\text { loadings }\end{array}$} & \multicolumn{3}{|c|}{$\begin{array}{c}\text { Rotation sums of squared } \\
\text { loadings }\end{array}$} \\
\hline & Total & $\begin{array}{c}\% \text { of } \\
\text { Variance }\end{array}$ & $\underset{\%}{\text { Cumulative }}$ & Total & $\begin{array}{c}\% \text { of } \\
\text { variance }\end{array}$ & $\underset{\%}{\text { Cumulative }}$ & Total & $\begin{array}{c}\% \text { of } \\
\text { variance }\end{array}$ & $\underset{\%}{\text { Cumulative }}$ \\
\hline 1 & 2.022 & 14.444 & 14.444 & 2.022 & 14.444 & 14.444 & 1.771 & 12.653 & 12.653 \\
\hline 2 & 1.805 & 12.891 & 27.335 & 1.805 & 12.891 & 27.335 & 1.701 & 12.151 & 24.804 \\
\hline 3 & 1.437 & 10.262 & 37.597 & 1.437 & 10.262 & 37.597 & 1.401 & 10.006 & 34.809 \\
\hline 4 & 1.338 & 9.558 & 47.155 & 1.338 & 9.558 & 47.155 & 1.377 & 9.835 & 44.645 \\
\hline 5 & 1.232 & 8.802 & 55.957 & 1.232 & 8.802 & 55.957 & 1.244 & 8.884 & 53.529 \\
\hline 6 & 1.054 & 7.528 & 63.485 & 1.054 & 7.528 & 63.485 & 1.236 & 8.827 & 62.356 \\
\hline 7 & 1.014 & 7.246 & 70.731 & 1.014 & 7.246 & 70.731 & 1.172 & 8.374 & 70.731 \\
\hline 8 & .789 & 5.634 & 76.365 & & & & & & \\
\hline 9 & .739 & 5.282 & 81.646 & & & & & & \\
\hline 10 & .673 & 4.807 & 86.454 & & & & & & \\
\hline 11 & .587 & 4.191 & 90.644 & & & & & & \\
\hline 12 & .507 & 3.624 & 94.268 & & & & & & \\
\hline 13 & .421 & 3.005 & 97.273 & & & & & & \\
\hline 14 & .382 & 2.727 & 100.000 & & & & & & \\
\hline
\end{tabular}


People who are healthier and have a positive work environment are less prone to sickness and appear to be happier than others. People who are religious perhaps suffer from fewer health risks and this combines with their work environment and thus contributes to their happiness. Indeed, this partially supports Rule's (2007) study in South Africa, which found that religious importance positively affects happiness. Thus, individuals who practice a religion may have a higher level of happiness than those who do not follow any religion.

Table 2

Rotated component matrix(a)

\begin{tabular}{|l|c|c|c|c|c|c|c|}
\hline & \multicolumn{7}{|c|}{ Component } \\
\hline Marital status & $\mathbf{1}$ & $\mathbf{2}$ & $\mathbf{3}$ & $\mathbf{4}$ & $\mathbf{5}$ & $\mathbf{6}$ & $\mathbf{7}$ \\
\hline Number of children & .828 & -.053 & -.026 & .051 & -.067 & -.152 & -.033 \\
\hline Health & .822 & .010 & .041 & -.043 & .079 & .182 & .048 \\
\hline Job/Working environment & -.245 & .809 & .079 & .057 & -.045 & -.029 & .089 \\
\hline Religion & .106 & .731 & -.096 & .083 & -.073 & .191 & -.218 \\
\hline Income received & .205 & .570 & -.041 & .298 & .114 & -.227 & .394 \\
\hline Level of education & .351 & -.052 & .782 & -.089 & -.106 & -.027 & -.078 \\
\hline Debt level & -.369 & .027 & .764 & -.076 & .090 & .018 & -.067 \\
\hline Friendships & .027 & -.001 & -.043 & .792 & .075 & .060 & -.151 \\
\hline Debt feel & -.035 & .304 & -.092 & .655 & -.168 & -.012 & .056 \\
\hline Age & .002 & .057 & -.064 & -.188 & .866 & -.060 & -.168 \\
\hline Types debt & -.003 & -.276 & .081 & .325 & .631 & .125 & .319 \\
\hline Ethnic group & .136 & -.022 & .220 & .172 & -.058 & .788 & .062 \\
\hline Gender & -.133 & .092 & -.325 & -.125 & .078 & .667 & -.120 \\
\hline
\end{tabular}

Extraction method: principal component analysis.

Rotation method: varimax with Kaiser normalization.

(a) Rotation converged in 8 iterations.

The third component, consisting of two factors (income and education, with weightings of 0.782 and 0.764 respectively) explained 10.2 per cent of the variation in happiness (Table 1 and 2). Both factors are almost of equal importance in influencing happiness, as their weights are nearly equal to each other. Better educated people tend to be more productive and earn a higher income, and hence tend to be happier in comparison with their counterparts with low education or income. Thus, as human capital influences an individual's earnings, it can also influence happiness. Income differences influence happiness; this possibly led Frey and Stutzer (2002:10) to argue that income does buy happiness. Individuals with lower income levels find a significant difference in their current level of happiness relative to those in the higher income group.

The influence of debt and friendship on subjective well-being was also examined. A rather surprising result emerged from the association between debt and happiness. These two factors belong to the fourth cluster and explain nearly 10 per cent of the variation in happiness. From Table (2), given that level of debt and friendship are found to be in the same component, it appears that one's friendly relationships with others are perhaps associated with the level of debt. As this is an unexpected result, the relationships between debt or ethnic patterns of debt and happiness is an area that requires further research with a qualitative and interactive approach. However, the case of consumer debt is interesting, as at any given level of income, increased debt may reflect increased consumption that may arise from easier access to credit. Perhaps this has a demonstration effect (Dutt, 2008), in that people who have more friends might contract more debt or rely on friends for loans. People often contract debt to impress others, to enhance consumption and to have access to durables because others do (Duesenberry, 1949) and thus tend to be happier. However, more debt can also be associated with reduced 
savings and less happiness.

Younger people tend to be less conservative and are more likely to contract debt; this may influence their happiness level. Age and how people feel about debt explain almost 9 per cent of the variation in happiness. Different ethnic groups tend to gravitate to certain types of debt. Hence, types of debt and the ethnic groups are in the same component, jointly explaining just over 7 per cent of the variation in happiness (Tables 1 and 2).

The last factor is gender, with a weighting of 0.880 , accounting for about 7 per cent of the variation in happiness. Jointly, all the above factors explained about 70 per cent of the variation in happiness. However, the first three components are of greater relative significance, as about 50 per cent of the variation in happiness is explained by social relationships, human capital and income. Diener and Seligman (2002) also found that social relationships, through satisfying family life, marriage and friendship, are most important for high happiness. In contrast, Perkins (1991) found that individuals who prefer high incomes, which accompany occupational stresses, to the detriment of close friendships and marriage describe themselves as unhappy. Overall, married people with education and children are found to be happier than others, but there is no significant difference in happiness between males and females.

\section{1}

\section{Recommendations}

There is no sole determinant that exclusively explains overall subjective well-being. The small sample size is a limitation to this study. However, on the basis of certain pointers, which correlate with those of other studies of a larger sample size, certain tentative recommendations many be inferred. But these suggestions are to be treated with care, owing to the data limitations of the study. As inferences are drawn from a small sample, the results cannot be generalized. Income has a relatively small influence on happiness. Higher income may enable an individual to buy material goods that have direct tangible benefits on subjective well-being, but material possessions do not contribute to lasting happiness. Improvements in income can make people happier for a while, but the effect fades rapidly, as aspirations change over time and people are habituated to different environmental settings. Although money is not everything to happiness, the acquisition of money can become an obsessive life-goal. The individual does not seem to be satisfied with what he has. He is concerned with more material needs, which increase with higher income.

Different conditions, mediating factors and outcomes make different people happy. The quality of life and relationships is critical for happiness and wellness, rather than just income. At the individual level, friendship and marriage have a profound positive effect on happiness, through companionship, and financial and emotional security, whereas separation dissolves a relationship (Ahuvia, 2012; Layard, 2011). As Nobel Prize Winner, Gary Becker (1993) argues, marriage enables the husband and wife or partners to be specialized producers of complementary household goods and services that enhance life satisfaction, and, by staying together, they profitably provide communal goods and services that further enhance happiness. One cannot be happy in isolation. People can enhance their happiness and life satisfaction if they can try to devote more time and energy to building family, friends and social networks that promote well-being. As Lane (2000) puts it, it is friendship and other social connections with other human beings that are important contributors to a rewarding and happy life. Marshall (1890:2) argued that "in religion, in the family affections and in friendship, even the poor may find scope for.... the highest source of happiness".

Time is a critical finite resource that can be spent on production (work) and consumption (leisure). More time spent at work implies less leisure time. It is understood that, at certain times, people may have to work long hours for purely financial reasons. There are social pressures to work more and engage in status consumption that provides temporary satisfaction, often with debt creation, which may be too strong to overcome individually. While more money can be earned through spending more time at paid work, this could be to the detriment of social and family relationships. A balance in allocating one's time between work 
and leisure is therefore desirable, so that 'quality' time can be spent on looking after one's health and building up and nurturing social relationships that result in higher levels of happiness and a better quality of life. Wilkinson and Pickett (2010:274) put it succinctly: "It is family, friends and community that matter to happiness". Jackson (2010:16) reinforces this point, arguing that happiness goes beyond material pleasures; it resides in the quality of our lives, in the health and wellbeing of our families, in the strength of our relationships and our trust in the community within the ecological limits of a finite planet. He suggests an alternative hedonism - a downshifting lifestyle over time for individuals where the emphasis is on simplicity. This is possible through devoting less time to material pursuits and greater time to gardening, walking, music, reading and the care of others, thus pursuing a way of living that is outwardly simple yet inwardly rich (Jackson, 2010:149).

As income is gained mainly from work, and considerable time is spent at work, employers can play a role in influencing happiness and hence the employees' productivity. If employees are satisfied with their jobs and work in a positive or fulfilling environment, they can become happier. Stress at work can invade the family environment. It is therefore in employers' interests to ensure a healthy working environment, as happier workers are more productive and absent themselves less frequently from work. This could contribute to greater profits for the firm for which they work. Employers may obtain better productivity by refining the internal work environment rather than improving pay. Thus, although income does not buy happiness, happiness can save income.

Health and education are also found to be associated with well-being. It is therefore suggested that policymakers should implement measures that allow for adequate access to health care and education for all citizens, enabling them to enjoy a better quality of life. The expansion of capability and empowerment through education is invariably welfareenhancing and augments human happiness (Sen, 2010:286). Increased access to education would also help to narrow South Africa's high levels of inequality by reducing the divergence of wealth and opportunities in the country. Societies with more trust and less inequality have fewer crimes and thus are happier (Wilkinson \& Pickett, 2010; Powdthavee, 2011). In the case of South Africa, Powdthavee (2011) found that crimes have a greater adverse effect on happiness than unemployment does.

Debt may not necessarily be a limitation to happiness, if it is entrepreneurially used to finance income generation activities and meet basic needs for shelter. Loans for activities that pay for themselves can raise the wealth and financial security of individuals. Hence debt instruments that finance income generating investments rather than consumption are to be supported, as they can lead to their holders attaining a higher level of happiness, and possibly reducing stress in their lives.

At the national level, people could be happier if there were more opportunities for them to gain an income through value-adding activities in the labour market rather than through transfer payments, in the form of social grants. This entails job creation, which could increase with economic growth. Studies conducted in other countries clearly show that unhappiness stems from unemployment (Oswald, 1997; Layard, 2011; The Economist, 19/2/11). Creating new jobs is essential for a renewed sense of well-being and national prosperity. Growth with employment could alleviate poverty, as people could earn higher incomes and gain self-esteem, allowing them to obtain more goods and services, and to lead a better and happier life.

\section{2}

\section{Conclusion}

The search for happiness is an important individual and national economic goal. At the macro level, more happiness may come from a sustained growth in GDP that would enable households to enjoy an improved quality of life, with rising income and employment opportunities, as well as fiscal redistribution. Individuals earn an income mainly from employment. The higher the level of income the more utility could be gained from consumption and the more satisfied a person would be. Having wealth may give an 
individual a sense of security, recognition and affordability. More income may also enable people to live happier and more fulfilled lives relative to those who are poor. But income accounts for only a small contribution to happiness.

Life circumstances, such as marriage, health and having children in the household and the nature of the working environment statistically make a greater contribution to happiness than income. While happiness can be a genetic aspect of ones personality, some people could become even happier if they were educated, had a healthy lifestyle, positive working relationships in the company of happy people and good friendships, and could contract affordable debt, enabling them to buy the right things.
Material aspirations change with gains in income. Some people seek happiness through gratification of the senses and material possessions. For them, the quest for more never ends, but leads them to the treadmill of unhappiness. However, one cannot expect to experience permanent happiness from impermanent worldly objects. Accordingly, some people seek spiritual rather than material happiness. This may be a matter of individual taste and preference. But good taste is what increases happiness, and vice versa (Layard, 2006:C30). Life satisfaction involves more than just income. Happiness can be bought in other 'currencies', like religion, education, friendships and family relationships.

\section{Acknowledgements}

The author would like to express his thanks to Professor S. Koch, Dr R. Simson, K. Ingleton, and the reviewers of this paper for their helpful comments and assistance.

\section{References}

AHUVIA, A. 2012. Wealth, consumption and happiness, in Psychology and Economic Behaviour, (ed.) Lewis, A., Cambridge: Cambridge University Press:199-226.

BECKER, G. 1993. A treatise on the family. Cambridge: Harvard University Press.

BISWAS-DIENER, R.M. 2007. Material wealth and subjective well-being, in The science of subjective wellbeing, (ed.) Eid, M. \& Larsen, R. J. London: Guilford Press:307-322.

BLACK, P.A, CALITZ, E. \& STEENKAMP, T.J. 2003. Public economics for South African Students. $\left(2^{\text {nd }}\right.$ ed.) Cape Town: Oxford University Press.

COAKES, S. \& STEED, L.K. 2003. SPSS without anguish. Queensland: John Wiley and Sons.

DIENER, E. \& SELIGMAN, M.E.P 2002. Very happy people. Psychological Science, 13(1):81-84.

DIXON, H.D. 1997. Controversy: economics and happiness, editorial note. Economic Journal, November, 107:1812-14.

DUESENBERRY, J.S. 1949. Income, savings and the theory of consumer behaviour. Cambridge: Harvard University Press.

DUTT, A.K. 2008. The dependence effect, consumption and happiness: Galbraith revisited. Review of Political Economy, 20(4):527-50.

DUTT, A.K. \& RADCLIFF, B. 2009. Happiness, economics and politics. Cheltenham, U.K: Edward Elgar. EASTERLIN, R. 2001. Income and happiness: toward a unified theory. Economic Journal, July, 111(473): 465-484.

FIELD, A. 2009. Discovering statistics using SPSS. London: Sage.

FRANK, R.H. 1999. Luxury fever. New York: Free Press.

FREY, B.S \& STUTZER, A. 2002. What can economists learn from happiness research? Journal of Economic Literature, June:402-435.

FREY, B.S \& STUTZER, A. 2000. Happiness, economy and institutions. Economic Journal, 110(446): 918-938.

FRIEDMAN, B. 2006. The moral consequences of economic growth. London: Penguin.

HAMILTON, C. 2004. The growth fetish. London: Pluto Press. 
HEUKAMP, F.H. \& ARINO, M.A. 2011. Does country matter for subjective well-being? Social Indicators Research, 100:155-370.

HINKS, T. \& GRUEN, C. 2007. What is the structure of South African happiness equations? Evidence from Quality of Life surveys. Social Indicators Research, 82:311-336

HDR. 2011. Human Development Report 2011: Sustainability and equity-a better future for all. New York: UNDP, Palgrave Macmillan.

HSIEH, C.M. 2004. Income and financial satisfaction among adults in the United States, Social Indicators Research, 66(3):249-66.

INGLEHART, R. 2009. Democracy and happiness: What causes what?, in Happiness, economics and politics, (ed.) Dutt, A.K and Radcliff, B., Cheltenham: Edward Elgar:256-270,

JACKSON, T. 2010. Prosperity without growth: Economics for a finite planet. London: Earthscan. JAMES, O. 2007. Affluenza. London: Vermilion.

KONOW, J. \& EARLEY, J. 1999. The hedonistic paradox: Is homo economicus happier? Mimeo, Loyola Marymount University.

LANE, E. 2000. The loss of happiness in market democracies. New Haven: Yale University Press. LAYARD, R. 2011. Happiness: Lessons from a new science. London: Penguin.

LAYARD, R. 2007. Happiness and public policy: A challenge to the profession, in Economics and psychology: A promising new cross-disciplinary field, (eds.) Frey, B.S. \& Stutzer, A. London: The MIT Press: 155-167.

LAYARD, R. 2006. Happiness and public policy: a challenge to the profession. Economic Journal, March, 116:C24-C33.

MAHADEA, D. \& RAWAT, T. 2008. Income, growth and happiness: An exploratory study, South African Journal of Economics, 76(2):276-290.

MALTHUS, T.R. 1798[1966]. An essay on the principle of population. London: Macmillan.

MARSHALL, A. 1890. Principles of economics. London: Macmillan.

NG, Y-K. 2006. Public policy implications of behavioural economics and happiness studies, in Ng, Y-K \& HO, L.S (eds.) Happiness and public policy. New York: Palgrave Macmillan.

NG, Y-K. 1997. A case for happiness, cardinalism, and interpersonal comparability. Economic Journal, 107(445):1848-58.

OSWALD, A. 1997. Happiness and economic performance. Economic Journal, November, 107(445):

1815-1831.

PERKINS, H.W. 1991. Religious commitment, yuppie values, and well-being in post-collegiate life. Review of Religious Research, 32(2):244-251.

PORTER, E. 2011. The price of everything. London: Heinemann.

POWDTHAVEE, N. 2007. Happiness and the standard of living: the case of South Africa, in Handbook on Economics of Happiness, (ed.) L. Bruni and P.L. Porta, MA, USA: Edward Elgar:447-486.

POWDTHAVEE, N. 2011. The happiness equation. London: Icon Books.

PUTMAN, R.D. 2001. Social capital: measurement and consequences, Canadian Journal of Policy Research, 2(1):41-51.

RULE, S. 2007. Religiosity and quality of life in South Africa. Social Indicators Research, 81:417-434.

SARB. 2011. The South African Reserve Bank quarterly bulletin, Pretoria, No. 259 (March).

SARB. 2010. The South African Reserve Bank quarterly bulletin, Pretoria, No. 258 (December).

SARIS, W. 2001. The relationship between income and satisfaction: The effect of measurement error and suppressor variables. Social Indicators Research, 43 (1):3-26.

SCITOVSKY, T. 1992. The joyless economy: An inquiry in human satisfaction and consumer dissatisfaction. Oxford: Oxford University Press.

SEN, A. 2010. The idea of justice. London: Penguin.

SHELDON, K.M. \& LYUBOMIRSKY, S. 2009. Change your actions, not your circumstances: an experimental test of the sustainable happiness model. In Happiness, economics and politics, (ed.) A.K. Dutt and B. Radcliff:324-342.

SMITH, A. 1759 [1980]. The theory of moral sentiments. Indianapolis, IN: Liberty Fund. 
STUTZER, A. 2001. What are the sources of happiness? In, Frey B.S. (eds.) Inspiring economics: human motivation in the political economy, 135-146, Northampton: Edward Elgar.

THE ECONOMIST. 2011. The awakening, 19/2/11:11-12.

VAVI, Z. 2011. Forging a better deal for South Africa's workers. Sunday Times, 6/2/2011.

VEENHOVEN, R. 1993. Happiness in nations: Subjective appreciation of life in 56 Nations. Rotterdam: Erasmus University.

VEENHOVEN, R. 1997. The utility of happiness. Social Indicators Research, 20:333-54.

VEENHOVEN, R. 2012. Happiness in South Africa, world database of happiness, Erasmus University Rotterdam, The Netherlands. Available at: http://worlddatabaseof happiness.eur.nl [accessed 2012-05-05]. VEENHOVEN, R. \& HAGERTY, M. 2006. Happiness in nations 1946-2004: A reply to Easterlin. Social Indicators Research, 79:421-436.

WILKINSON, R. and PICKETT, K. 2010. The spirit level: Why equality is better for everyone. London: Penguin. 